\title{
Bio-etiek sonder grense en menswaardigheid: 'n Gereformeerd-etiese beoordeling
}

\begin{tabular}{|c|c|}
\hline \multicolumn{2}{|c|}{$\begin{array}{l}\text { Author: } \\
\text { Riaan Rheeder }\end{array}$} \\
\hline \multicolumn{2}{|c|}{$\begin{array}{l}\text { Affiliation: } \\
{ }^{1} \text { Unit for the Development of } \\
\text { Reformed Theology, North- } \\
\text { West University, South Africa }\end{array}$} \\
\hline \multicolumn{2}{|c|}{$\begin{array}{l}\text { Correspondence to: } \\
\text { Riaan Rheeder }\end{array}$} \\
\hline \multicolumn{2}{|c|}{$\begin{array}{l}\text { Email: } \\
\text { riaan.rheeder@nwu.ac.za }\end{array}$} \\
\hline \multicolumn{2}{|c|}{$\begin{array}{l}\text { Postal address: } \\
\text { PO Box 62, Potchefstroom } \\
\text { 2520, South Africa }\end{array}$} \\
\hline \multicolumn{2}{|c|}{$\begin{array}{l}\text { Dates: } \\
\text { Received: } 29 \text { Jan. } 2013 \\
\text { Accepted: } 01 \text { Aug. } 2013 \\
\text { Published: } 04 \text { Oct. } 2013 \\
\text { Republished: } 07 \text { Oct. } 2013\end{array}$} \\
\hline \multicolumn{2}{|c|}{$\begin{array}{l}\text { How to cite this article: } \\
\text { Rheeder, R., 2013, 'Bio- } \\
\text { etiek sonder grense en } \\
\text { menswaardigheid: 'n } \\
\text { Gereformeerd-etiese } \\
\text { beoordeling', Verbum et } \\
\text { Ecclesia } 34(1) \text {, Art. \#830, } \\
11 \text { pages. http://dx.doi. } \\
\text { org/10.4102/ve.v34i1.830 }\end{array}$} \\
\hline \multicolumn{2}{|c|}{$\begin{array}{l}\text { Note: } \\
\text { This article was republished } \\
\text { with the correct affiliation of } \\
\text { the author. }\end{array}$} \\
\hline \multicolumn{2}{|c|}{$\begin{array}{l}\text { Copyright: } \\
\text { (C) 2013. The Authors. } \\
\text { Licensee: AOSIS } \\
\text { OpenJournals. This wo } \\
\text { is licensed under the } \\
\text { Creative Commons } \\
\text { Attribution License. }\end{array}$} \\
\hline \multicolumn{2}{|l|}{ Read online: } \\
\hline aida & $\begin{array}{l}\text { Scan this QR } \\
\text { code with your } \\
\text { smart phone or } \\
\text { mobile device } \\
\text { to read online. }\end{array}$ \\
\hline
\end{tabular}

Bioethics without boundaries and human dignity: A Reformed-ethical assessment. The Universal Declaration of Bioethics and Human Rights (UDBH) seeks to guide the world community in ethical principles with regard to medicine, life sciences and related technologies. Human dignity as a principle was requested by the world community and serves as a point of departure in most human rights instruments, as well as in the UDBH. Human dignity serves as a foundation for ethical principles and human rights. In this article, attention was given to the question of whether human dignity could be accepted as part of the Biblical message. Human dignity as a principle and grounding in the UDBH was accepted by most major religions of the world. There exists today a universal consensus that human dignity is an extremely important concept in bioethics. In light of the Reformed tradition, all human beings have dignity, as they had been created in the image of God. Because God is absolute value, humans have derived, but definite value. Human dignity is not just a status, but also a command. All the ethical principles and human rights in the UDBH should be regarded as a way of giving expression to the dignity of man. When the dignity of the humans beings is infringed upon, an undignified image of God is revealed, and serves as a direct insult to God.

\section{Inleidend}

In 2004 maak Vorster (2004:85) die volgende opmerking: 'New generations of human rights are still being developed' en sy rede daarvoor is: 'History is on the side of human rights.' In die jaar 2005 is die Universele Deklarasie van Bio-etiek en Menseregte (UDBM) eenparig deur al die lidlande van United Nations Educational, Scientific and Cultural Organization (UNESCO) aanvaar (UNESCO 2006). Dit is die eerste en enigste teks op die gebied van die bio-etiek waartoe al die lande van die wêreld hulself verbind het. Daardeur erken hulle die bestaan van fundamentele etiese beginsels op die terrein van die bio-etiek (Ten Have 2011). Hiermee saam het al die lidlande aangedui dat die begrip menswaardigheid deel van hierdie verklaring moet wees. Volgens Pellegrino (2009) is UDBM 'n logiese en tydige uitbreiding van die beginsels soos gevind in die Universele Deklarasie van Menseregte (1948).

Die doel van die UDBM in die eerste plek is die beskikbaarstelling van 'n lys van etiese beginsels as rigtingwysers vir besluite en praktyke deur die owerhede (wetgewing en beleid), groepe, gemeenskappe, institusies, korporasies, openbaar en privaat, op die terrein van die biomediese praktyk (UNESCO 2006, artikels 1.1 ${ }^{1} ; 2^{2}{ }^{2}, b^{3}, d^{4}$; Andorno 2009b). Volgens Andorno (2009a:95, 2009b:225) 'the whole Declaration [is] conceived as an extension of international human rights law into the field of biomedicine', wat beteken dat geformuleerde etiese beginsels as regte verstaan moet word. Die tweede doel van die UDBM is die bevordering van die beskerming van (bio-etiese) menseregte in die deklarasie asook menseregte in die algemeen (UNESCO 2006, 2 $\mathrm{c}^{5}$ ).

In die artikel gaan eerstens aandag gegee word aan die gebruik en betekenis van menswaardigheid binne die UDBM, en tweedens, teen die agtergrond van die begrip menswaardigheid binne die UDBM, gaan gepoog word om die begrip menswaardigheid binne die gereformeerde teologie te begrond.

1.1. This Declaration addresses ethical issues related to medicine, life sciences and associated technologies as applied to human beings, taking into account their social, legal and environmental dimensions' (UNESCO 2006:6).

2.'(a) to provide a universal framework of principles and procedures to guide States in the formulation of their legislation, policies or other instruments in the field of bioethics ...' (UNESCO 2006:6).

3.'(b) to guide the actions of individuals, groups, communities, institutions and corporations, public and private ...' (UNESCO 2006:6).

4.'(d) to recognize the importance of freedom of scientific research and the benefits derived from scientific and technological developments, while stressing the need for such research and developments to occur within the framework of ethical principles set out in this Declaration and to respect human dignity, human rights and fundamental freedoms ...' (UNESCO 2006:6).

5.'(c) to promote respect for human dignity and protect human rights, by ensuring respect for the life of human beings, and fundamental freedoms, consistent with international human rights law' (UNESCO 2006:6). 


\section{Menswaardigheid in die Universele Deklarasie van Bio-etiek en Menseregte \\ Die gebruik}

Een van die kenmerkende eienskappe van (algemene) menseregte-instrumente is die feit dat menswaardigheid (human dignity) as vertrekpunt geneem word. Só kan na die veelbesproke Universele Deklarasie van Menseregte van 1948 verwys word ${ }^{6}$. Menswaardigheid vorm ook die kern van die twee prominente menseregte-instrumente (konvensies) wat in 1966 aanvaar is, naamlik die Internasionale Verbond oor Burger- en Politieke Regte en Internasionale Verbond oor Ekonomiese, Sosiale en Kulturele Regte ${ }^{7}$ (Andorno 2009b).

Ook menseregte-instrumente (deklarasies) wat bio-etiese problematiek aanspreek, neem menswaardigheid as hulle grondslag. Hier is die Universele Verklaring oor die Menslike Genoom en Menseregte van UNESCO (1997) ${ }^{8}$ en die Verdrag oor Menseregte en Biogeneeskunde van die Raad van Europa (1997) ${ }^{9}$ ter sprake. Andorno (2009a, 2009b) maak die opmerking dat menswaardigheid die hart en oorkoepelende beginsel vorm van die meeste internasionale menseregteinstrumente wat op die biopraktyk toegespits is.

Daarom is dit seker nie onverwags dat die UDBM (2005) menswaardigheid as eerste en funderende beginsel in die deklarasie ingeskryf het nie (Andorno 2009b). In die voorwoord word dit duidelik gestel dat menswaardigheid erken en gerespekteer moet word (UNESCO 2006). In artikel 3 van die deklarasie word dit duidelik gestel dat menswaardigheid ten volle gerespekteer moet word $^{10}$. Hiermee saam word respek en bevordering van menswaardigheid juis as een van die doelwitte van die deklarasie gestel (artikels 2c,d) ${ }^{11}$ terwyl artikels 11, 12 en 28 hulle direk beroep op die agting vir menswaardigheid. Die Verklarende Memorandum oor die Uitbreiding van die Voorlopige Konsepverklaring oor Universele Norme oor Bioetiek (UNESCO 2005:1-2) bevestig die belangrikheid van die begrip menswaardigheid: 'A most important achievement of the draft declaration is that it anchors the principles that it espouses firmly in the rules governing human dignity, human rights and fundamental freedoms.'

Dit is van groot belang om in gedagte te hou dat die bevordering van menswaardigheid een van die fundamentele

$6 . ' W h e r e a s$ recognition of the inherent dignity and of the equal and inalienable rights of all members of the human family is the foundation of freedom, justice and peace in the world ...' (United Nations [UN] 1948:n.p.).

7.'Considering that, in accordance with the principles proclaimed in the Charter of the United Nations, recognition of the inherent dignity and of the equal and inalienable rights of all members of the human family is the foundation of freedom, justice and peace in the world ...' (UN 1966a:n.p., 1966b:n.p.).

8.'Article 2 (a) Everyone has a right to respect for their dignity and for their rights regardless of their genetic characteristics' (UNESCO 1997:42).

9.'Article 1 - Purpose and object. Parties to this Convention shall protect the dignity and identity of all human beings and guarantee everyone, without discrimination, respect for their integrity and other rights and fundamental freedoms with regard to the application of biology and medicine' (Council of Europe 1997:n.p.).

10.'1. Human dignity, human rights and fundamental freedoms are to be fully respected' (UNESCO 2006:6)

11.'The aims of this Declaration are ... (c) to promote respect for human dignity and protect human rights ...' (UNESCO 2006:6). beginsels was wat die meeste deur die lidlande versoek is tydens die konsultasieproses in die opstelling van die UDBM (International Bioethics Committee [IBC] 2004; Andorno 2009a).

Waarom is die begrip menswaardigheid so belangrik? Waarskynlik omdat daar'n nou verband tussen waardigheid, die reg tot lewe, fisiese en psigiese integriteit bestaan. Laasgenoemde is belangrike begrippe binne die bio-etiek en daarom word vervolgens aandag aan die betekenis van menswaardigheid gegee.

\section{Die betekenis}

Die begrip menswaardigheid word algemeen in internasionale menseregte-instrumente gebruik, maar word nooit gedefinieer nie en is ook nie ' $n$ term wat maklik is om te omskryf nie (Andorno 2009a; Gushee 2011). Hierdie gebrek aan 'n definisie het sommige bio-etici tot die oortuiging laat kom dat menswaardigheid bloot 'n slagspreuk is sonder enige relevansie. Die begrip is bloot 'n sinoniem vir 'respek vir outonomiteit' vir pasiënte en navorsingsobjekte. Die begrip kan maar laat vaar word en geen verlies sal ondervind word nie (Macklin 2003). Tog sou dit foutief wees om uit die afwesigheid van 'n amptelike definisie af te lei dat die begrip menswaardigheid sonder betekenis is. Al afleiding wat gemaak kan word, is dat dit vir die wêreldgemeenskap moeilik is om binne 'n plurale omgewing 'n gemeenskaplike definisie te vind. Dit is waar dat die begrip misbruik en soms verkeerd geïnterpreteer word. Dieselfde is ook waar van alle morele en juridiese beginsels (geregtigheid, vryheid, outonomie), wat ook gewoonlik nie deur die wet gedefinieer word nie, juis omdat dit ' $n$ onmoontlike taak is om hierdie begrippe in ' $n$ transkulturele situasie so te definieer dat almal daarmee gemaklik sal wees. Daarom is die uitgangspunt van die opstellers van menseregtedeklarasies die ou Romeinse stelling van omnis definitio in iure periculosa est [elke definisie in die reg is gevaarlik] (Andorno 2009b).

Wat beteken menswaardigheid? Dit is bekend dat die Universele Deklarasie van Menseregte (1948), wat menswaardigheid kategories bevestig, die direkte gevolg was van die skokkende, onmenslike (onmenswaardige) optrede tydens die Tweede Wêreldoorlog en veral die optrede van die Nazi-regime tussen 1941 en 1945 (Andorno 2009b; Gushee 2011; Hollenbach 2003; Vorster 2004). Daarom is dit belangrik om te probeer begryp hoe die Nazi-regime menswaardigheid verstaan het, wat die optrede teenoor hulle medemens gemotiveer het. Hollenbach (2003) stel dit soos volg:

The Universal Declaration of Human Rights thus bases its proclamation of human rights norms on the practical experience of their violation. The preamble of the Declaration first alludes to the two twentieth-century world wars ... It implicitly invokes the Nazi attempt so exterminate the Jewish people ... (p. 233)

Dit word aanvaar dat die sosiaal-Darwinisme (asook ekonomiese faktore, rassisme en totalitarisme) se verstaan van menswaardigheid 'n groot invloed uitgeoefen het op die Nazi-ideologie wat gelei het tot die mees onmenslike 'biomediese' praktyke (O’Mathúna 2006). 
Volgens O'Mathúna (2006; vgl. ook Pope 2007) het 'n aantal oortuiginge na die verskyning van The Origin of Species ontstaan wat sommige mense se siening van menswaardigheid, ook in Nazi-Duitsland, radikaal verander het. Sosiaal-Darwinisme word beskou as die toepassing van Darwin se biologiese teorieë in 'n sosiale en etiese gedragskode en bestaan uit die volgende vyf oortuiginge:

- Die wese van etiek is relativisties en nie universeel nie. Etiek en moraliteit het saam met die mens ontstaan en ontwikkel. Die menslike samelewing ontwikkel en verander en daarom moet etiek verander soos die omgewing verander. Mense se siening van menswaardigheid moet verander. Etiek is 'n stuk gereedskap wat evolusionêr ontwikkel en die eliminasie wat die swakke moet ondersteun.

- Die onderskeid tussen mens en dier is vaag, omdat die mens uit die dier ontwikkel het. Die mens is inherent soos 'n dier.

- Menslike ongelykheid bestaan in die natuur en lei tot grade van geskiktheid. Ras, fisiese en verstandelike vermoëns (of goeie genetiese eienskappe) is vereistes vir menswaardigheid en is nie ' $n$ inherente gegewe nie.

- Aan die laer kant van die spektrum het sommige lewe byna geen waarde (of kwaliteit) nie en is daarom 'lives not worth living'.

- Natuurlike seleksie wys dat die oorlewing van die sterkste (as uitwissing van swak gene) die wet van die natuur is. Daarom is beleid of gedrag wat die doodmaak van onwaardige mense motiveer wel eties. Uitwissing en oorlog is middele om die swakkes te elimineer.

Dit moet genoem word dat Darwin nie 'n etiese teorie op grond van sy evolusieteorie ontwikkel het nie (Pope 2007; Küng 2011). In die lig van bogenoemde is dit verstaanbaar dat twee Duitse akademici, Binding en Hoche ([1920] 1992), 'n medikus en juris, in 1920 kan beweer dat sommige mense waardeloos is en daarom aan gewetenlose behandeling onderwerp kan word:

Is there human life which has so utterly forfeited its claim to worth that its continuation has forever lost all value both for the bearer of that life and for society? Initially, this question is in every case to be answered with certainty: Yes .... There was a time, now considered barbaric, in which eliminating those who were born unfit for life, or who later became so, was taken for granted. Then came the phase, continuing into the present, in which, finally, preserving every existence, no matter how worthless, stood as the highest moral value. (Part iv, vi)

Dr Leo Alexander (2013), 'n raadgewer tydens die Neurenberg-verhoor, wat die Nazi's se 'mediese' praktyke bestudeer het, noteer die volgende (vgl. ook O'Mathúna 2006):

All destructiveness ultimately leads to self-destruction; the fate of the SS and of Nazi Germany is an eloquent example. ... The beginnings at first were merely a subtle shift in emphasis in the basic attitude of the physicians. It started with the acceptance of the attitude, basic in the euthanasia movement, that there is such a thing as life not worthy to be lived. This attitude in its early stages concerned itself merely with the severely and chronically sick. (p. 419, 424)
Wanneer die mens geen waarde het nie en ook beskou word as niks meer of minder as die dier nie, word die mens soos en selfs as minder as 'n dier behandel. O'Mathúna (2006) stel hierdie beskouing soos volg:

However, the early twentieth century social Darwinists used this idea (humans viewed as simply part of the continuum of animal life) to treat some humans in ways that previously had been reserved for animals. Rather than elevating the status of all species, they rejected belief in the inherent dignity of all human life and justified the killing of innocent humans believed to be of lower status than some animals. (p. 10)

Dit is duidelik dat wanneer menswaardigheid ontken of geïgnoreer word, dit tot die mees minagtende gedrag teenoor die medemens lei. Die feit dat die Nazi-regime sommige mense se menswaardigheid ontken het, het gelei tot die wreedste mediese praktyke soos eutanasie sonder toestemming (siek, verswakte kinders en volwassenes, sommiges selfs met net ligte depressie, ens., vgl. Alexander 2013), geforseerde sterilisasie (soms op die onmenslikste wyse, vgl. Alexander 2013; Runzheimer \& Larsen 2011), eugenese en uiters wrede eksperimentering met mense (o.a. lewendige operasies, urelange onderdompeling in yswater, ens., vgl. Alexander 2013; O’Mathúna 2006; Runzheimer \& Larsen 2011). Seiple (2010) verwys na die feit dat sommige mense vandag nog gesien en behandel word as wesens sonder waarde. Hy bespreek verskeie voorbeelde, maar een wat sonder twyfel uitstaan is die verhaal van 'n negejarige Somaliese meisie, met die naam Boshorro, wat hy in 'n hospitaal ontmoet het. Hierdie meisie was verhonger, omdat meisies in die tyd van hongersnood op die minste kos geregtig is. Boshorro is na die hospitaal gebring nadat ' $n$ gat in haar maag geskiet is. Seiple (2010) vertel verder:

But the pathetic image before me exhibited one more indignity. I noticed that the sleeves of her dress had been cut out. When I inquired as to why this was done, a medical staffer replied without emotion: 'We had to reduce her value. If the dress were whole, she would have been vulnerable to the bad elements of our society. We had to reduce her vulnerability by reducing her value'. (p. 325)

Hierdie bespreking het nie tot 'n definisie van menswaardigheid gelei het nie, maar uit die oorsigtelike stof kan intuitief aangevoel word waarom die mensdom menswaardigheid kort na die Tweede Wêreldoorlog as 'n etiese beginsel of vertrekpunt vir alle mense aanvaar het. Seiple (2010) gee ook nie ' $n$ definisie van die term nie, maar bespreek moderne voorbeelde waar mense onmenswaardig behandel is, waaruit spontaan aangevoel kan word wat menswaardigheid is. Hollenbach (2003) volg ook hierdie gedagtelyn en skryf die volgende:

The practical rationale sketched in the preamble reflects the fact that it was not philosophical argumentation of a theoretical nature that led to the drafting of the Universal declaration. Rather, it was the negative experiences of war and what subsequently was named 'genocide' that gave rise to a desire to identify practical standards to which all nations could be held accountable. (p. 234)

Met menswaardigheid wou die mensdom sê dat alle mense waarde het en met waardigheid gehanteer sal word. Alhoewel die internasionale instrumente nie 'n skerp omlynde definisie 
van die begrip van menswaardigheid gee nie, bied hierdie instrumente tog ' $n$ hermeneutiese ontsluiting of gevoel van die begrip.

Met hierdie verduideliking in gedagte kan daar nou beweeg word na hoe die menseregte-instrumente in die algemeen dié begrip in breë terme verstaan. Die eerste afleiding word gevind in die voorwoord van die Universele Deklarasie van Menseregte (1948), waarvolgens menswaardigheid '[is] inherent ... to all members of the human family' (UN 1948:n.p.). Die term 'inherent' het ' $n$ ontologiese betekenis in die sin dat dit waardigheid as deel van die intrinsieke aard van die mens ag. Die woordvorm 'inherent' toon aan hoe die mens is, en daarom is waardigheid onskeibaar van die menslike natuur. Waardigheid is nie ' $n$ toevallige eienskap van sommige mense, of 'n waarde as gevolg van sekere persoonlike eienskappe van die mens soos oud of jonk, man of vrou, siek of gesond nie, maar is 'n onvoorwaardelike waarde of waardigheid van elke mens, omdat die mens qua mens is (Andorno 2009b; Pellegrino 2009). In die lig van laasgenoemde kan die mens ook nie van sy regte vervreem word nie (Gushee 2011).

Die tweede afleiding oor die verstaan van menswaardigheid word gevind in artikel 1 van die Universele Deklarasie van Menseregte wat stel dat alle mense is 'free and equal in dignity and rights' (UN 1948:n.p.). Omdat alle mense, kragtens qua menswees, menswaardig is, beteken dit dat alle mense gelyk is en daarom behels dit gelyke menseregte (Pellegrino 2009). Dit is ook die rede waarom diskriminasie, waar mense ongelyk behandel word, 'n aantasting van menswaardigheid is (Andorno 2009b).

Die derde afleiding word gemaak uit die twee internasionale konvensies van siviele en politieke regte, asook van ekonomiese, maatskaplike en kulturele regte (1966) wat stel dat 'these rights derive from the inherent dignity of the human person' (UN 1966a:n.p., 1966b:n.p.). Dit beteken dat menseregte uit menswaardigheid ontwikkel en daarom nie iets is wat aan mense gegee word deur byvoorbeeld die owerheid nie, maar waardes is wat inherent tot die mens behoort, en daarom ook nie van hulle weggeneem kan word nie (Andorno 2009b). Regerings skep nie regte nie, maar erken bloot regte wat onafhanklik bestaan en regerings voorafgaan (Gushee 2011).

Ook die UDBM gee nie ' $n$ definisie van menswaardigheid nie. Die Verklarende Memorandum oor die Uitbreiding van die Voorlopige Konsepverklaring oor Universele Norme oor Bio-etiek (2005), wat nie normatiewe waarde het nie, gee 'n aanduiding hoe die opstellers van die UDBM menswaardigheid verstaan het:

Respect for human dignity flows from the recognition that all persons have unconditional worth, each having the capacity to determine his or her own moral destiny. Showing disrespect to human dignity could lead to the instrumentalization of the human person. (p. 6)

Vir Immanuel Kant is die mens nie ' $n$ ding nie (Starke 2001). Menswaardigheid dui op die intrinsieke (inherente, ingebore) waarde [value] van elke mens, omdat die mens tot die menslike spesie behoort, wat per definisie vir alle mense waar is. 'Such a notion embodies the idea that something is due to human beings because of the sole fact that he or she is human' (Andorno 2009a:94).

Die erkenning van menswaardigheid erken nie grade van menslike waarde nie en dit is ook nie iets wat bygekry of verloor kan word nie. Dit impliseer dat aan alle mense respek betoon moet word ongeag hulle ouderdom, geslag, gesondheid, status, sosiale of etniese oorsprong, politieke idees of godsdiens. Dit is dus duidelik dat menswaardigheid en respek vir persone nie dieselfde saak is nie. Respek volg op menswaardigheid, soos die klank van 'n kerkklok volg op die beweging van die klok. Menswaardigheid vorm die rasionaal vir die respek vir alle mense (Andorno 2009b).

Andorno (2009b) beweer dat alhoewel die UDBM nie die begrip menswaardigheid omskryf nie, maak die UDBM 'n besliste bydrae tot die verstaan van die begrip. Artikel $3.2^{12}$ stipuleer dat 'the interests and welfare of the individual should have priority over the sole interest of science or society'. Hierdie artikel is ' $n$ direkte uitvloeisel van die beginsel van respek vir menswaardigheid (artikel 3.1) en beklemtoon twee fundamentele idees. Die eerste is dat wetenskap nie ' $n$ doel op sigself is nie, maar is ' $n$ manier waarop die welstand van die individue en wetenskap verbeter kan word; tweedens mag die mens nie tot blote instrumente gereduseer word ter wille van die wetenskap nie.

\section{Andorno (2009a) stel hierdie uitgangspunt soos volg:}

However, in democratic societies, people do not live for the sake of society or technology, but have their own purpose, which greatly transcend the boundaries of social of scientific interests. (p. 228)

Laasgenoemde neem nie die feit weg nie dat die mens as gemeenskapswese volgens eie vermoëns en voorkeur inderdaad gemeenskaplike goed in die samelewing moet bevorder

Hierdie verstaan van menswaardigheid van die UDBM sluit aan by die bekende Kantiaanse stelling wat aanvoer dat die mens as doel op sigself bestaan en nooit as 'n middel tot doel gebruik mag word nie. Die rede hiervoor is dat die mens nie ' $n$ ding [thing] is nie, maar' $n$ persoon, wat nie bloot as ' $n$ instrument gebruik kan word nie. Alhoewel dinge ' $n$ prys of waarde het, is dit 'n tipe waarde waarvoor daar ' $n$ ekwivalent bestaan, terwyl die mens onvervangbaar is. Hierdie verstaan van waardigheid omvat die vereiste van die nie-instrumentalisering van die mens wat besonder belangrik is in die bio-etiek. Dit beteken dat geen mens sonder ingeligte toestemming aan mediese navorsing wat 'n hoë risiko inhou, onderwerp mag word nie, nie eens wanneer baie waardevolle kennis bekom mag word nie. Dit is ook onaanvaarbaar dat

12. Hierdie artikel kom vir die eerste keer voor in die Helsinki Deklarasie (1964), asook die Universele Deklarasie oor die Menslike Genoom en Menseregte (1997) en die Europese Raad se deklarasie oor menseregte en biomedisyne (1997). 
mense in uiterste armoede hulle organe moet verkoop om hulle of hulle familie te versorg. Niemand het die reg om menslike klone te skep of om vooraf die genetiese inhoud van 'n kind te kies bloot om die wense van potensiële ouers of belange van die samelewing te bevredig nie (Andorno 2009b).

Die gedagte van die mens as doel op sigself (of nieinstrumentalisering) is ook belangrik in alledaagse mediese praktyk en beklemtoon die uniekheid van elke mens en sy of haar spesifieke behoeftes. So 'n verstaan van menswaardigheid kan die kwaliteit van die dokterpasiëntverhouding verbeter, omdat die mens, ongeag die aard van sy diagnose, nie ' $n$ 'saak', of 'n 'siekte' is nie, maar 'n persoon met 'n unieke karakter (Andorno 2009b).

Ten spyte van bogenoemde omlyning van die betekenis van menswaardigheid is waarskynlik korrek om aan te voer dat die betekenis van menswaardigheid ook oorgelaat moet word aan ' $n$ intuïtiewe vertolking wat in 'n groot mate deur kulturele faktore bepaal word.

\section{Die reg}

Uit bogenoemde bespreking is dit duidelik dat die begrip menswaardigheid in die menseregte-instrumente voorkom en dus as beginsel in die bio-etiek funksioneer. Menswaardigheid word beskou as 'n fondament waaruit menseregte ontwikkel en vorm die hoogste rasionaal waaruit menseregte in die biomediese omgewing voortvloei (Andorno 2009b; vgl. ook Pope 2007). Die Internasionale Verbond oor Burger- en Politieke Regte en Internasionale Verbond oor Ekonomiese, Sosiale en Kulturele Regte stel dit duidelik dat menseregte ontleen [derive] word aan die menswaardigheid van die mens (UN 1966a, 1966b), daarom dat Andorno na menswaardigheid as die 'shaping principle', 'overarching principle', 'keynote', 'ultimate rationale' en 'deepest justification' verwys, terwyl die UDBM menswaardigheid as 'n 'anker' aandui (UNESCO 2006 ${ }^{13}$ ). Pellegrino (2009) beskryf menswaardigheid as die 'leitmotiv' en noem dat die begrip die begronding van regte en etiek in die UDBM vorm.

Alhoewel die begrip menswaardigheid van groot betekenis binne die internasionale menseregte-instrumente is, moet erken word dat die begrip nie' $n$ magiese beginsel is wat alleen alle bio-etiese dilemmas aanspreek of oplos nie (Andorno 2009b). Behalwe die eie betekenis, moet menswaardigheid in die eerste plek ook breër vir die bio-etiek gekonkretiseer of funksioneel gemaak word deur etiese begrippe soos 'ingeligte toestemming', 'fisiese integriteit', 'vertroulikheid', 'niediskriminasie'; en die formulering van hierdie beginsels maak van menseregteterminologie en -begrippe gebruik (Andorno 2009a). Dus kan die UDBM so vertolk word dat artikels $4-17$ as bio-etiese beginsels 'n beskrywing gee van wat menswaardigheid in 'n bio-etiese konteks beteken. ' $n$

13.In dealing with ethical issues raised by medicine, life sciences and associated technologies as applied to human beings, the Declaration, as reflected in its title, anchors the principles it endorses in the rules that govern respect for human dignity, human rights and fundamental freedoms' (UNESCO 2006:2, voorwoord, Koïchiro Matsuura).
Kurrikulum wat deur UNESCO se akademici opgestel is, en wat wêreldwyd gebruik word om regeringsamptenare en gesondheidswerkers in die verstaan van die UDBM te begelei, stel hierdie waarheid soos volg (UNESCO 2008):

The principles manifested in articles $4-17$ of the Universal Declaration on Bioethics and Human Rights give a proper framework to respect patients' dignity and rights and clarify the specific context of human rights in bioethics. (p. 21)

Nou word dit duidelik waarom artikel $3.1^{14}$ in die verwysing na menswaardigheid ook die saak van menseregte en fundamentele vryhede byvoeg. Daar is dus sprake van beginsels en statutêre norme. Die hele UDBM word ook beskou as 'n uitbreiding van internasionale menseregtebepalings in die veld van die biogeneeskunde (Andorno 2009a). Die voorsitter van die IBC-komitee (regter M. Kirby) verantwoordelik vir die opstelling van die konsepdeklarasie, beskou die feit dat bio-etiese analise (beginsels) in 'n menseregteraamwerk aangebied word, as 'the most important achievement of the text' (Kirby 2006:126) ${ }^{15}$. Ook die formuleringgroep (drafting group) beklemtoon:

[s]tressed the importance of taking international human rights legislation as the essential framework and starting point for the development of bioethical principles, as was the case with the Universal Declaration on the Human Genome and Human Rights of UNESCO. (UNESCO 2005:2) ${ }^{16}$

'n Verdere belangrike rede waarom bio-etiese beginsels binne ' $n$ menseregteraamwerk aangebied word, is omdat die raamwerk help om etiese beginsels te universaliseer (vgl. ook Gushee 2011). Omdat die wêreld al hoe meer interafhanklik word en gesondheidsorg en farmaseutiese maatskappye globaliseer, is die mees effektiewe manier om die verskynsel te bestuur, die toepassing van menseregte. Dit het inderdaad nodig geword om mense op die terrein van die gesondheidsorg te beskerm. As globale instrument transendeer menseregte ook kulturele diversiteit. Alhoewel daar 'n nou verband tussen etiek en menseregte is (vgl. Veatch 2012), is Andorno (2009b) korrek as hy daarop wys dat (bio-)etiek nie afdwingbaar is nie, maar die wet (of regte) wel; en dat bio-etiese beginsels daarom ook binne 'n menseregteraamwerk aangebied word.

\section{Samevatting}

Die UDBM wil die wêreldgemeenskap begelei in etiese beginsels wat binne die geneeskunde, lewenswetenskappe en verwante tegnologie gebruik kan word. Menswaardigheid, wat deur die wêreldgemeenskap versoek is, dien as vertrekpunt en beginsel binne die meeste menseregteinstrumente asook binne die UDBM. Menswaardigheid dien as begronding van etiese beginsels en menseregte. Vervolgens gaan aandag gegee word aan die vraag of menswaardigheid as deel van die Bybelse boodskap aanvaar kan word.

14.1.Human dignity, human rights and fundamental freedoms are to be fully respected' (UNESCO 2006:5).

15.'It will ensure that, henceforth, bioethical and human rights analysis will be more closely integrated. This will be the most significant achievement of the Declaration (Kirby 2006:126).

16.Die samevoeging van etiek en wet (of regte) is nie vreemd aan die Skrif nie, as Waldron (2010) daarop wys dat die imago Dei volgens Genesis 9:8 binne die juridiese en menseregtekonteks staan. 


\section{Menswaardigheid in die Christelike tradisie \\ Inleidend}

Hans Küng (2011) skryf oor menseregte-instrumente die volgende:

Over the last decades initiatives of inter-religious dialogue and co-operation have grown all over the world. In this dialogue the world's religions have rediscovered that their own fundamental ethical teachings support and deepen those secular ethical values that are enshrined in the Universal Declaration of Human Rights. (p. 2674)

In bogenoemde paragraaf verwys Küng in die algemeen na menseregte-instrumente, en hierby kan sonder twyfel ingesluit word die UDBM, wat sekulêre etiese waardes bevat. Ook Gushee (2011) beskou menseregtedeklarasies as internasionaal en sekulêr. In die lig van bogenoemde ontstaan die vraag nou of menswaardigheid as grondbeginsel in artikel 3 van die UDBM vanuit ' $n$ Christelike en gereformeerde paradigma onderskryf kan word, en of dit 'n suiwer sekulêre beginsel en uitgangspunt is. In die lig van laasgenoemde vraag sal gepoog word om die gedagte van menswaardigheid as 'n Bybelse moontlikheid te begrond. Oor die begronding van die sekulêre gedagte van menswaardigheid as inderdaad gereformeerd en dus Bybels skryf Waldron (2010):

Foundations matter: they are not just nailed on to the underside of a theory or a body of law as an after-thought. If we are looking for foundations for our convictions about human rights, we are looking for something that may well make a difference to what it is that we believe [outeur se beklemtoning] about rights. This is particularly true if we say we are looking for religious foundations. (p. 233)

In aansluiting by bogenoemde aanmerking maak Küng myns insiens twee belangrike opmerkings. Die eerste is dat verskeie godsdienste, ook die Christelike godsdiens, die etiese waardes ondersteun wat in die menseregte-instrumente voorkom (vergelyk ook Ten Have 2011). Hiervan is die gedagte van menswaardigheid ' $n$ besondere voorbeeld. 'n Duidelike bewys word gevind in die feit dat verskeie godsdienstige verteenwoordigers, naamlik Islam, Confucianisme, Boeddhisme, Hindoeïsme, Rooms-Katolisisme en die Joodse tradisie menswaardigheid heelhartig tydens die ontwikkeling van die UDBM as begronding en etiese beginsel onderskryf het (Pellegrino 2009; UNESCO 2004). Daarom is Pellegrino (2009) korrek as hy aanvoer:

Given the wide range of cultural and religious values represented, these results give evidence for a remarkable degree of agreement on the ethical and legal primacy of human dignity. (p. 100)

Van besondere belang is die tweede punt naamlik dat die godsdienstige tradisie 'n bepaalde etiese waarde verdiep. Uit bogenoemde bespreking is dit duidelik dat daar nie konsensus is oor presies wat onder menswaardigheid verstaan moet word nie. Die Christelike tradisie kan help in dié verband deur ' $n$ verklaring te gee wat onder menswaardigheid verstaan kan word. Op dié wyse kan die begrip vir die Christen duideliker word en verdiep. In die Christelike en gereformeerde tradisie word menslike waardigheid afgelei van die feit dat die mens na die beeld van God geskape is, terwyl ander tradisies weer die klem laat val op spesiale kenmerke van die mense self (Ten Have 2011). Daarom is Andorno (2009a) korrek as hy aanvoer:

Because, in one way or another, the idea of human dignity has to do with the spiritual [outeur se beklemtoning] dimension of human existence and relates to the conviction that what makes us human cannot be found only at the biological or genetic level. (pp. 93-94)

\section{'n Christelik-gereformeerde verstaan}

\section{'n Algemene erkenning}

Daar word vandag algemeen aanvaar dat die begrip menswaardigheid van uiterste belang vir die bio-etiek is (Kass 2008:298; vgl. ook Pope 2007:196-213): 'Today, human dignity is of paramount importance especially in matters bioethical.' In 'n resente ensikliek van die Rooms-Katolieke Kerk (RKK) ten opsigte van bio-etiek word die volgende gesê:

The dignity of a person must be recognized in every human being from conception to natural death. This fundamental principle expresses a great yes to human life and must be at the center of ethical reflection on biomedical research, which has an ever greater importance in today's world. (RKK 2008:par. 1.; vgl. ook Sulmasy 2008)

Meilaender (2008a) erken die dilemma rondom die begrip van menswaardigheid, maar meen dit bied geen verskoning om nie hierdie begrip te gebruik nie. Inteendeel. Vorster (2007), 'n teoloog uit die gereformeerde tradisie bied 'n kragtige erkenning van die begrip wanneer hy aanvoer dat die saak van menswaardigheid tot die hart van die Bybelse boodskap hoort. Dit is inderdaad 'n universeel erkende (Bybelse) begrip waarvan die betekenis en toepassing in die bio-etiek saam bepeins moet word:

At the same time, human history has also shown real progress in the understanding and recognition of the value and dignity of every person as the foundation of the rights and ethical imperatives by which human society has been, and continues to be structured. (RKK 2008:par. 36) (sien konklusie)

Vervolgens sal aan hermeneutiese vertrekpunte aandag gegee word in die hantering van die Skrif en daarna sal die beeldskap van die mens in die lig van die Skrif bespreek word.

\section{Hermeneutiese vertrekpunte}

Churchland (2008) is van oordeel dat daar geen finale en onaanvegbare waarheidsbron in die bio-etiek bestaan waaruit presies bepaal kan word wat menswaardigheid beteken nie. Die enigste werkbare bron is 'fair-minded' [billike] kompromieë van logiese denke. Hierteenoor word gekies vir die verantwoordelike gebruik van die Bybel as brondokument binne die Christelike en gereformeerde tradisie waaruit reg en verkeerd beoordeel kan word (1 Tess 2:13; vgl. Van Wyk 1991; De Bruyn 1993; Ps 119:105; Miga 6:8). Na my mening verwoord Vorster (2007) verantwoordelike Skrifverklaring wanneer hy skryf:

The interpreter should thus be extremely careful not to derive ethical principles from biblical parts without consulting the 
whole message ... the application of parts of Scripture without the light of the total message usually leads to distorted ethical views. (p. 8)

Verskeie wetenskaplikes gaan uit van die standpunt dat die skeppingsleer een van die vernaamste teologiese leerstukke is wat as bron vir die Christelike en gereformeerde etiek dien (Holmes 1995; Østnor et al. 1995; Wright 1995). Etiese voorskrifte moet teologies begrond word (Brown 1995). Die etiek put uit die waarheid dat God geskep het en dat dit wat Hy geskep het, voor die sondeval goed genoem word (RKK 2008). Die skeppingsnarratief (Gen 1 en 2 ) is van besondere waarde omdat menswaardigheid in die skeppingsleer gefundeer is, spesifiek binne die leerstuk dat die mens na die beeld van God geskep is (vgl. ook Higginson 1995; Douma 1997; Waldron 2010). Die mens as beeld van God vorm die onderbou van die hele Ou Testament (Vorster 2008) en ipso facto die hele Skrif. 'If you want to understand how God looks at biotech, get into the beginning of the book Genesis - and stay there' (p. 50) (Tada \& Cameron 2006). In die begin het God die mens na sy beeld geskape (Gen 1 en 2) en in die geskepte natuur van hierdie eerste mensepaar word God se oorspronklike wese en doel vir die mens en die huwelik afgelei (Holmes 1995; Vorster 2007). Ook Grogan (1995) is van mening dat die mens as beeld van God sy gepaardgaande menswaardigheid as 'n belangrike oorweging in bioetiese probleme hanteer moet word (vgl. Østnor et al. 1995).

\section{Imago Dei as gegewe}

Vir baie lank was die begrip menswaardigheid nie as 'n belangrike teologiese term beskou nie, en tot baie onlangs was dié term nooit in bio-etiese beredenering gebruik nie (Sulmasy 2008). Dit het egter verander. Die term menswaardigheid kom nie in die Bybel voor nie, maar wel die saak. Die Bybel is duidelik daaroor dat God die hemel en die aarde en alles op die aarde, ook diere en plante, geskape het. God het ook die mens geskape. Op verskeie plekke in die Skrif word gelees dat God die mens na sy beeld geskape het: "Toe het God gesê: "Kom ons maak die mens as ons verteenwoordiger, ons beeld ..."' (Gen 1:26; vgl. ook Gen 1:27; 5:1-3; 9:5-7; Ps 8 [1983-vertaling]). Die feit dat God die mens na sy beeld geskape het, bring die mens sonder twyfel in 'n besondere verband met God (Vorster 2007). Die skepping is 'n geordende hiërargie waarin God gekies het om aan die mens sy beeld te verbind. Wat ook duidelik uit hierdie Skrifgedeeltes is, is die feit dat die hele mensdom na die beeld van God geskape is, en omdat God alle mense gemaak het, is alle mense voor God gelyk (Spr 22:2; vgl. ook Waldron 2010). Aansluitend hierby, omdat die beeldskap voor enige etniese, rasse- of nasionale verdeling bestaan het (sien Gen 10) word enige vorm van etnosentrisme, rassisme of nasionale superioriteit veroordeel (Middleton 2011).

Wat beteken die begrip mens as beeld van God? Die 'mens as beeld' beteken nie dat die mens God is nie. Volgens König (2006) dui die gedagte van die mens as beeld van God daarop dat daar ' $n$ besondere ooreenkoms tussen God en die mens is (vgl. ook Eckman 2008). In Genesis 5 is daar direk na mekaar twee verwysings na 'beeld'. Die eerste is 'n herhaling van
Genesis 1 waar God die mens na sy beeld geskape het (Gen $1: 1)$, en direk daarna 'n verwysing na die geboorte van Adam se seun Set van wie dan gesê word: 'sy beeld, een soos hyself' (Gen 1:3). As dit gesê word van 'n pa en 'n seun, kan 'n mens vermoed dit beteken: daar is ' $n$ besondere ooreenkoms.

'Beeld van God' hou dan die gedagte in dat die geskape mens soos God is ('een soos hyself'). Daar is 'n besondere ooreenkoms tussen God en die mens. Dit lê opgesluit in die

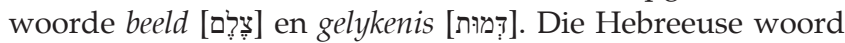
vir beeld en gelykenis druk sinonieme gedagtes uit en word daarom afwisselend gebruik (Heyns 1992; Middleton 2011). Volgens Grogan (1995) word die sinonieme vir beklemtoning gebruik, wat beteken dat God wil hê dat die geskape mens homself sonder twyfel as sy beeld sal verstaan. Hoe kan die ooreenkoms verstaan word? Die beeld van God hou verband met wie en hoe God in Homself is (König 2001). Dit gaan hier oor 'n basiese gelykheid tussen God en mens waar die mens inderdaad ongelooflik na aan God is. Van geen ander skepsel is so iets waar nie (König 2010). Hier is sprake van 'n ontologiese strekking (vgl. Waldron 2010): soos God is, so is die mens ${ }^{17}$, maar dan in ' $n$ beperkte of analogiese sin; ' $n$ beeld moet immers tog naastenby soos die afgebeelde wees of is (König 2012), iets soos pa en seun. Die mens is weerspieëling van God self (Heyns 1992). Omdat ons bedoel is om God se beeld te wees, sal ons uit ons kennis oor sy 'is', kan aflei hoe ons is (König 2001; vgl. ook O’Mathúna 1995).

\section{Menswaardigheid as status}

Soos bo vermeld dui beeldskap op die ooreenkoms tussen God en die mens en daarom word die afleiding gemaak dat beeldskap op die unieke en verhewe status (of belangrikheid) van die mens dui (Østnor et al. 1995; Sulmasy 2008). Vorster (2011, vgl. ook Waldron 2010), na deeglike bespreking van die mens as beeld van God, som die implikasie van die imago Dei vir die teologiese antropologie soos volg op:

Because God creates the human after his image the human possesses an inherent dignity that animals do not enjoy ... all human beings possesses an equal worth ... (p. 22)

Vir die Christelike etiek rus die oneindige waarde van elke mens in die feit dat hy of sy na die beeld van God geskape is (Gelernter 2008; Grogan 1995; O’Mathúna 1995; Tada \& Cameron 2006; Vorster 2008).$^{18}$ Ook Post (2011) verbind die beeldskap van die mens met menslike waarde, waardigheid en onskendbaarheid. 'Die mens, en dit geld vir alle mense, het 'n besondere waarde én waardigheid', skryf König (2001:140).

Hierdie status of waarde word inderdaad afgelei uit die feit dat nét die mens na die beeld van die waardevolle God geskape is (Imago Dei). Hoe God 'is', so is die mens. In hierdie hiërargie van bestaan vorm God aksiomaties die hoogste vorm van bestaan en waardigheid. God vertoon waardigheid (Higginson 1995). Daarom dat Hy in Openbaring 4:11 as dié

17.This balance of rights and responsibilities - inherent in the nature of God, and, by extension, in the nature of humans who represents God's image on earth - is critically important in how one approaches human rights' (Seiple 2010:322).

18.'The fulfillment of this duty implies courageous opposition to all those practices which result in grave and unjust discrimination against unborn human beings, who have the dignity of a person, created like others in the image of God' (RKK 2008:par. 36). 
waardevolle ('A $\xi 10 \varsigma$ ) besing word (vgl. ook Heb 3:3). Hy is die Absolute in waardigheid. As God absolute waardigheid is en die mens sy beeld, dan besit die mens afgeleide, maar definitiewe waarde (Matt 6:26). Daarom dat die volgende in Psalm 8:6 van die mens gelees word (1953-vertaling): 'U het hom 'n weinig minder gemaak as 'n goddelike wese en hom met eer en heerlikheid gekroon.' Eer en heerlikheid is terme wat vir die waardige God gebruik word (König 2010). Volgens Vorster (2008) word in hierdie Skrifgedeelte 'n treffende voorbeeld van die mens se waarde gevind. ${ }^{19}$ Esterhuyse (2009) stel dit soos volg:

Dis bes moontlik dat die storieverteller dié woorde [mens as beeld van God - outeur] gekies het om nie bloot ' $n$ antropomorfe voorstelling van die baie abstrakte begrip "god" te gee nie, maar ook die mag en verhewe posisie van die mens in die skepping aan te dui. (p. 48)

Die mens as beeld van God verenig die mens met die (waardevolle) wese van God en daarom bestaan menswaardigheid. Waldron (2010) stel dit soos volg:

One idea behind human rights is an emphasis on the value to be accorded each person. This seems straightforward enough in the light of imago Dei. That doctrine seems to imply that there is something precious, even sacred, in each human being - something which command respect of the kind that is commanded by the very being of God. (p. 222)

Die besondere status van die mens of menswaardigheid word ook Christologies begrond. Die verkondiging dat die Seun van God die menslike natuur aangeneem het, en as mens heerlikheid ( $\delta$ ó $\alpha$ ) $)$ vertoon, bevestig die waardigheid van die mens (Joh 1:14). Gushee (2011) skryf in die verband:

The incarnation - in which God takes flesh in Jesus Christ, ministers to society's outcasts, teaches the obligation of love and mercy to all, suffers at the hands of humans, and dies for our salvation - serves as the ultimate grounding of Christian belief in die sanctity, dignity and rights of each and every human being. (p. 389)

Die mens besit besondere waarde, want hulle deel aan die goddelike natuur (2 Pet 1:4; RKK 2008). Seiple (2010:328) vat dit soos volg saam: 'Human value is one of the great "take aways" from a God who loved and a Christ who died.'

Dit is ook belangrik om op te merk dat Christus se lewe en kruisdood as vernederende omstandighede (onmenswaardige omstandighede) nie sy inherente waardigheid aangetas het nie. Hy is steeds as (beeld van) God aanbid, ten spyte van die feit dat Hy'n onwaardige kriminele dood aan die kruis gesterf het (Meilaender 2008b). Die mens behou sy waardigheid ten spyte van sy omstandighede. Die waarde van mense word verder ondersteun in God se misterieuse keuse om aan die mens alleen sy liefde te bewys (Kraynak 2008; Kass 2008). Volgens Kass (2008) word die waardigheid van die mens deur sy voortreflikheid [excellence] en besondere prestasies in die geskiedenis bevestig en geilllustreer. Dit moet net genoem word dat die waarde van mens nie afgelei word uit die inherente goedheid van die mens nie, maar dat dit'n waarde is wat in die verbinding met God aan die mens toegeken is (Peters 1996). God gee waardigheid juis as gevolg van die sonde (Vorster 2008).

19.Douma (1997:44) sê: 'Wij mogen de positie van de mens dus hoog aanslaan.'

\section{Menswaardigheid as opdrag}

Seiple (2010) skryf:

With the words, 'made in the image of God', Christianity also finds its social obligation, the maintenance of values between and among people, the enhancement of the human condition regardless of context. (p. 325)

Omdat die mens bedoel is om God se beeld te wees, sal ons uit ons kennis oor Hom ook kan aflei nie net hoe die mens is nie, maar hoe die mens behoort te wees (König 2001; vgl. ook O'Mathúna 1995). In die Hebreeuse woorde vir beeld lê ook die gedagte opgesluit dat die mens wat die beeld is, ook die beeld moet laat skyn, moet weerspieël of moet wees. Ons moet soos God wees (Ef 4:32; 1 Pet 1:15; Luk 6:36 en Matt 5:48) wat beteken ons moet Godvormige mense wees (König 2012). Anders gesê, die mens moet God se eienskappe (sy is; deugde) in die wêreld verteenwoordig (O’Mathúna 1995). Die mens moet God in die wêreld manifesteer (RKK 2008). Dit is die wese van 'n beeld om te vertoon; daarom moet die mens ook beeld wees. Die mens is die kopie of refleksie van die oorspronklike (Vorster 2007). Om verder te verduidelik: die mens moet soos God, wat liefde is (1 Joh 4:8), liefde vertoon (König 2010). In die Nuwe Testament is 'n verskeidenheid verwysings met heelwat inhoud. Uit Efesiërs 4:24 word gesien dat die beeldwees van God as 'n eksplisiete opdrag na die mens kom, naamlik om as beelddraers op te tree. Hier word ' $n$ verwysing gevind na Genesis 1 , maar met ' $n$ verskil. Die Ou Testament plaas die klem op die werklikheid dat die mens die beeld van God is (beperkte ontologie), terwyl die Nuwe Testament die klem daarop plaas dat die mens die beeld van God ook moet wees. Beeldskap beteken dat God aan die mens 'n sekere rol toeken: elkeen moet God se verteenwoordiger op aarde wees. Om beeld van God te wees beteken dat die mens die gedagtes, dade en gesindheid van God moet weerspieël (vgl. De Bruyn 1993).

Christus word ook die beeld van God genoem, wat beteken dat God met sy volle wese in Hom woon (Kol 1:19; 2:9; König 2012). Juis hoe ons die beeld van God moet uitstraal, vind sy voorbeeld in Christus. Anders gesê, uit hoe Christus is, kan ons ook aflei hoe ons moet wees. Christus as beeld van God is die prototipe van die ware mensheid as beeld van God (Fil 3:21; Kol 3:10; Bridger 1995; Middleton 2011). Hy is die tweede Adam. Daarom dat die Skrif die gelowige kan oproep om gelykvormig aan die beeld van Christus te word (Rom 8:29; 2 Kor 3:18). Om aan Christus se beeld te konformeer, beteken ' $n$ ingesteldheid op konkrete liefdesdade teenoor jou naaste. In die Pauliniese literatuur word die beeld van God op Jesus oorgedra. In werklikheid is dit nie nodig om 'n onderskeid tussen die beeld van God en die beeld van Christus te tref nie (König 2001). As die perfekte beeld van God, is Christus die voor-beeld van ware humaniteit of van menswaardige optrede. Dit beteken 'n lewe van liefde (wat genesing insluit, Matt 14:14), diens, vergifnis en nederigheid (kyk Fil 2:5; Kol 3:13; Ef 4:32; 5:2; Joh 13:14, 15). Christus se beeld beteken dat Hy vir ander lewe (Brown 1995). Hierdie beeld van Christus moet geweerspieël word en vorm die imago Christi (Bridger 1995). Die mens wat die voorbeeld van Christus navolg, dus die imago Christi word, vorm die ware 
beeld van God (O'Mathúna 1995). Ons kan bogenoemde argumentasie soos volg saamvat: ons is die beeld van God as ons in ons hele lewe soos hy leef, as ons lewe aan hom herinner, as ons waardesisteem syne verteenwoordig. Daar moet ooreenkoms wees tussen hom en ons (König 2006). In Christus se aardse optrede sien ons hoe mense menswaardig behandel word.

Vorster stel die duidelike implikasie van bogenoemde beredenering vir die verstaan van menswaardigheid (2007; vgl. ook Sulmasy 2008):

Dignity is a status that God awards the human, and therefore the human should live according to his status and treat others according to their status. (p. 20)

Daarom gee God aan die mens bepaalde pligte. Pligte erken menswaardigheid (Heyns 1992; Gelernter 2008). Respek begin by die erkenning van die gegewe dat die mens menswaardig is en daarom kan die ad rem-afleiding gemaak word dat respek uit die waarheid van menswaardigheid vloei (vgl. Sulmasy 2008). Omdat die mens menswaardig is, moet hy God, homself en ander mense respekteer (RKK 2008). Hierdie afleiding is baie belangrik vir die bio-etiek. Die mens as beeld van God moet ook met menswaardigheid handel word. Die mens as beeld van God het dus die taak om voor die wêreld [coram mundo] van die menswaardigheid van die mens te getuig (Østnor et al. 1995).

Vroeër is daarop gewys dat menswaardigheid in die UDBM (as begrondingsbeginsel, vgl. 2.3) vir die bio-etiek gekonkretiseer of funksioneel gemaak word deur etiese begrippe soos 'ingeligte toestemming', 'fisiese integriteit', 'vertroulikheid' en 'nie-diskriminasie' en daarom kan die UDBM só vertolk word dat artikels $4-17$ as bio-etiese beginsels ' $n$ beskrywing gee wat menswaardigheid in ' $n$ bioetiese konteks beteken. Indien hierdie beginsels die toets van die Skrif deurstaan, kan hulle beskou word as liefdesdade teenoor die medemens. In die lig van bogenoemde beredenering kan die nakoming van hierdie beginsels beskou word as die uitvoering van die opdrag om beeld van God te wees en gee dit daarom uitdrukking aan menswaardigheid. Inderdaad is Yiu (2012:113-114) korrek as hy aanvoer dat menseregte (artikels 4-17 van die UDBM) 'n uitdrukking van liefde is, en dat liefde in dié sin uitdrukking gee aan menswaardigheid (Matt 22:37-40; 1 Joh 2:7, 19, 29; 2 Joh 6).

Wat is die teologiese implikasie wanneer die menswaardigheid van die mens aangetas word? Anders gevra: hoe raak dit God wanneer die mens binne die geneeskunde, lewenswetenskappe of verwante tegnologie onmenswaardig behandel word? Waldron (2010) verwys na 'n verhaal wat in die Talmoed voorkom, naamlik die 'gelykenis van die tweeling' (wat ook kan help om Deut 21:23 te verhelder): twee broers, 'n identiese tweeling, het in dieselfde stad gewoon. Die een was die koning en ander het 'n rower geword. Die koning het die opdrag gegee dat die rower in die openbaar gehang moet word. Maar almal wat die rower gesien het, het gesê: 'Die koning is gehang!' Die koning het toe die opdrag gegee om die rower af te haal. Die implikasie van hierdie gelykenis, inderdaad die implikasie van imago Dei, is dat wanneer ons mense op 'n sekere wyse behandel, byvoorbeeld wanneer hulle gemartel of hulle liggame vermink word, word 'n onwaardige beeld van God na buite vertoon. Beide die persoon wat onmenswaardig optree en die een teen wie onmenswaardig opgetree word, vertoon ' $n$ afskuwelike beeld van God. In dié sin word 'n afbeelding van God gemaak. In aansluiting by laasgenoemde gedagte wys Middleton (2011) daarop dat die aantasting van die menswaardigheid 'n direkte belediging van God is. Hy verwys onder andere na Jakobus 3:9, wat die Outestamentiese wysheidstradisie eggo wat daarop dui dat die mens God verteenwoordig, sodat die onderdrukking van (of goedwees vir) die armes en weerlose mense gelykstaande aan die belediging (of eer) van God is (Spr 14:31, 17:5 en 22:2). 'n Soortgelyke gedagte is onderliggend aan die gelykenis van die skape en bokke (Matt 25:31-46), waar aangedui word dat onmenswaardige optrede teenoor die mens, en dus disrespek vir sy menswaardigheid, kan beskou word direkte disrespek vir Jesus Christus (Matt 25:40).

Dit is tersaaklik om hier kortliks te verwys na die feit dat sommige individue daarvan oortuig is dat die mens na die sondeval (Gen 3) sy menswaardigheid verloor het en dus geen waarde meer het nie. Die implikasie is dat die begrip menswaardigheid irrelevant vir die bio-etiek en dus nie ' $n$ opdrag aan die mens is nie. Hierteenoor kan vermeld word dat alhoewel die beeldskap van die mens na die sondeval aangetas is, die mens nie totaal die beeld van God verloor het nie. Dit word bevestig deur die feit dat mens as beeld in Genesis 5:1-2 herhaal word en dat hierdie beeld na die volgende geslagte oorgedra word (Gen 5:3; Middleton 2011:395). Hiermee saam word die beeldskap van die mens in die verhaal van Noag, na die sondeval, herbevestig (Kraynak 2008; Middleton 2011; Gen 9:4). Die sekerheid dat die mens nog steeds beeld van God is, word in die Nuwe Testament bevestig (vgl. 1 Kor 11:7; Jak 3:9; Grogan 1995; König 2001). Laasgenoemde neem nie die gegewe feit weg dat God se beeld in die mens wel deur die sonde versteur is nie. Die mens wat God se liefde moet weerspieël, kan nou ook haat. Die mens se ooreenkoms (verhouding) met God en sy naaste is nou verdraai. In plaas daarvan om die beeld van God te weerspieël en die besondere ooreenkoms uit te straal, wil die mens eerder self die oorspronklike beeld, God self, word (vgl. Gen 3:5). Omdat die mens se beeldskap nie in besondere menslike eienskappe gefundeer is nie, maar 'n status is wat aan die mens toegesê is, kan 'n mens nie die beeld verloor nie.

\section{Samevatting}

Menswaardigheid as beginsel en begronding in die UDBM is deur die meeste groot godsdienste van wêreld bekragtig. Daar bestaan vandag 'n algemene konsensus dat menswaardigheid 'n uiters belangrike begrip binne die bioetiek is. In die lig van die gereformeerde tradisie kan bely word dat die mens as menswaardig beskou moet word, omdat hy of sy na die beeld van God geskape is. Omdat God absolute waarde is, besit die mens afgeleide maar besliste waarde. 
Menswaardigheid is nie net 'n status nie, maar word ook as opdrag aan die mens gegee. Die mens wat beeld van God is, moet ook beeld van God wees, wat beteken dat God se beeld aan die ander mens vertoon moet word. Al die etiese beginsels en menseregte in die UDBM kan beskou word as 'n wyse waarop uitdrukking aan die waardigheid van die mens gegee kan word.

Wanneer 'n mens die menswaardigheid van die ander mens aantas, word ' $n$ onwaardige beeld van God vertoon en dien dit as 'n direkte belediging van God.

\section{Gevolgtrekking}

Eckman (2008) vat die begronding van menswaardigheid in die Skrif soos volg saam:

God provides the absolute criteria for determining the value of human beings. Because physical, economic, mental, and social/ cultural criteria are all arbitrary and relative, they are inadequate for assigning value to human. God created humans in His image (Gen 1:26ff.) and established His absolute criteria for their value. (pp. 226-227)

Sonder twyfel kan menswaardigheid vanuit die gereformeerde teologiese tradisie aanvaar word. Mense het waarde en daarom moet die beginsels van menswaardigheid binne die UDBM aanvaar en ondersteun word. Binne die globale omgewing van die geneeskunde, lewenswetenskappe en verwante tegnologie moet mense met menswaardigheid behandel word. Vanuit 'n gereformeerde sienswyse word God sigbaar gemaak (en verkondig) op die wyse waarop mense binne die mediese omgewing behandel word.

\section{Erkenning \\ Mededingende belange}

Die outeur verklaar dat hy geen finansiële of persoonlike verbintenisse het met enige partye wat hom nadelig of voordelig kon beïnvloed het in die skryf van hierdie artikel nie.

\section{Literatuurverwysings}

Alexander, L., 2013, 'Medical Science under dictatorship', in M.T. Donohoe (ed.), Public Health and Social justice, A Jossey-Bass Reader, pp. 409-426, Jossey-Bass, San Francisco.

Andorno, R., 2009a, 'Article 3: Human dignity and human rights', in H. Ten Have \& M.S Jean (eds.), The UNESCO Universal Declaration on Bioethics and Human Rights. Background, Principles and Application, pp. 91-98, United Nations Educational, Background, Principles and Application,
Scientific and Cultural Organization, Paris.

Andorno, R., 2009b, 'Human dignity and human rights as common ground for global ethics', Journal of Medicine and Philosophy 34, 223-240. http://dx.doi. org/10.1093/jmp/jhp023, PMid:19386998

Binding, K. \& Hoche, A., [1920] 1992, 'Permitting the destruction of unworthy life: Its extent and form', Law \& Medicine 8(2), 231-265.

Bridger, F.W., 1995, 'Humanity', in D.J. Atkinson \& D.H. Field (eds.), New dictionary of Christian ethics and pastoral theology, pp. 21-27, Intervarsity, Downers Grove.

Brown, R.G., 1995, 'Clones, chimeras, and the image of God: Lesson from the Barthian bioethics', in J.F. Kilner, N.M. de S. Cameron \& D.L. Schiedermayer (eds.), Bioetichs and the future of medicine: A Christian appraisal, pp. 238-249, Eerdmans, Grand Rapids.

Churchland, P.S., 2008, 'Human dignity for a neurophilosophical perspective', in Human dignity and bioethics: Essays commissioned by the President's Council on Bioethics, viewed 08 October 2008, from http://bioethics.georgetown.edu/pcbe/ reports/human_dignity/

Council of Europe, 1997, 'Convention for the Protection of Human Rights and Dignity of the Human Being with regard to the Application of Biology and Medicine: Convention on Human Rights and Biomedicine', in Council of Europe, viewed on 20 November 2012, from http://conventions.coe.int/Treaty/en/Treaties/ $\mathrm{Html} / 164$.htm
De Bruyn, P.J., 1993, Die tien gebooie, Varia, Midrand.

Douma, J., 1997, Medische ethiek, Uitgeverij van den Berg, Kampen.

Eckman, J.M., 2008, Exploring church history. A guide to history, world religions, and ethics, Crossway Books, Wheaton, III.

Esterhuyse, W., 2009, God en die Gode van Egipte. In die voetspore van die onsienlike, Lux Verbi.BM, Wellington.

Gelernter, D., 2008, 'The irreducibly religious character of human dignity', in Human dignity and bioethics: Essays commissioned by the President's Council on Bioethics, viewed 08 October 2008, from http://bioethics.georgetown.edu/pcbe/ reports/human_dignity/

Grogan, G.W., 1995, 'Image of God', in D.J. Atkinson \& D.H. Field (eds.), New dictionary of Christian ethics and pastoral theology, pp. 476-477, Intervarsity, Downers Grove.

Gushee, D.P., 2011, 'Human Rights', in J.B. Green (ed.), Dictionary of Scripture and Ethics, pp. 387-389, Baker Publishing Group, Grand Rapids.

Heyns, J.A., 1992, Inleiding tot die dogmatiek aan hand van die Nederlandse Geloofsbelydenis, NG Kerkboekandel, Pretoria.

Higginson, R.A., 1995, 'Ethics of medical care', in D.J. Atkinson \& D.H. Field (eds.) New dictionary of Christian ethics and pastoral theology, pp. 93-99, Intervarsity, Downers Grove.

Holmes, A.F., 1995, 'Creation', in D.J. Atkinson \& D.H. Field (eds.), New dictionary of Christian ethics and pastoral theology, pp. 268-270, Intervarsity, Downers Grove.

Hollenbach, D., 2003, 'The global face of public faith', Politics, Human rights, and Christian Ethics, Georgetown University Press, Washington, D.C.

Internasional Bioethics Committee (IBC), 2004, 'Information meeting with IGBC on the progress of the elaboration of a Declaration on Universal Norms on Bioethics', viewed on 02 December 2012, from http://portal.unesco.org/pv_obj_cache/ pv obj id C2ECE6D996142C3EA4C54E51397D24078D2F0100/filename/ IGBC7July2004Rep_en.pdf

Kass, L.R., 2008, 'Defending human dignity', in Human dignity and bioethics: Essays commissioned by the President's Council on Bioethics, viewed 08 October 2008 from http://bioethics.georgetown.edu/pcbe/reports/human_dignity/

Kirby, K., 2006, 'UNESCO and universal principles in bioethics: What's next?' in International Bioethics committee Of Unesco (IBC) Twelfth Session. Proceedings', viewed on 20 November 2012, from http://unesdoc.unesco.org/images/ 0014/001484/148404e.pdf

König, A., 2001, Fokus op die 300 geloofsurae wat mense die meeste vra: Sleutelbegrippe van die Christelik geloof: 'n Verwysingsgids vir elke huis, Lux Verbi. $\mathrm{BM}$, Wellington.

König, A., 2006, Die groot geloofswoordeboek: Meer as 500 kernwoorde van die Christelike geloof maklik gemaak, Christelike Uitgewersmaatskappy, Vereeniging.

König, A., 2010, Alle paaie lei na Jesus. Hoe die groot temas van die Bybel op Jesus uitloop, Christelike Uitgewersmaatskappy, Vereeniging.

König, A., 2012, Wie is God? Kan ons regtig nog in Hom glo?, Christelike uitgewersmaatskappy, Vereeniging.

Kraynak, R.P., 2008, 'Human dignity and the mystery of the human soul', in Human dignity and bioethics: Essays commissioned by the President's Council on Bioethics, viewed 08 October 2008, from http://bioethics.georgetown.edu/pcbe/ reports/human_dignity/

Küng, H., 2011, 'What I believe', Beskikbaar by http://www.amazon.com. (Kindle uitgawe).

Macklin, R., 2003, 'Dignity is a useless concept', British Medical Journal 327 1419, viewed on 20 November 2012, from http://bmj.com/cgi/content/ 1419, viewed on
full/327/7429/1419

Meilaender, G., 2008a, 'Commentary on Churchland', in Human dignity and bioethics: Essays commissioned by the President's Council on Bioethics, viewed 08 October 2008, from http://bioethics.georgetown.edu/pcbe/reports/human_dignity/

Meilaender, G., 2008b, 'Human dignity: Exploring and explicating the Council's vision' in Human dignity and bioethics: Essays commissioned by the President's Council on Bioethics', viewed 08 October 2008, from http://bioethics.georgetown.edu/ pcbe/reports/human_dignity/

Middleton, J.R., 2011, 'Image of God', in J.B. Green (ed.), Dictionary of Scripture and ethics, pp. 394-397, Baker Publishing Group, Grand Rapids.

O'Mathúna, D.P., 1995, 'The Bible and abortion: What of the "Image of God"?', in J.F. Kilner, N.M. de S. Cameron \& D.L. Schiedermayer (eds.), Bioethics and the future of medicine: A Christian appraisal, pp. 199-211, Eerdmans, Grand Rapids.

O'Mathúna, D.P., 2006, 'Human dignity in the Nazi era: Implications for contemporary bioethics', Biomed Central Medical Ethics 7(2), viewed on 11 December 2012, bioethics', Biomed Central Medical Ethics 7(2), view
from http://www.biomedcentral.com/1472-6939/7/2

$\emptyset$ stnor, L., Hallamaa, J., Anderson, S., Björnsson, S.V., Nilsson, G. \& Thunberg, L., 1995, 'The Lutheran approach to bioethics', in V. Mortensen (ed.), Life and death: Moral implications of biotechnology, pp. 9-34, WCC, Geneva.

Pellegrino, E.D., 2009, 'Article 4: Benefit and Harm', in H. Ten Have \& M.S. Jean (eds.), The UNESCO Universal Declaration on Bioethics and Human Rights. Background, Principles and Application, pp. 99-109, United Nations Educational, Scientific and Cultural Organization, Paris.

Peters, T., 1996, For the love of children. Genetic technology and the future of the family, Westminster John Knox Press, Louisville, KY.

Pope, S.J., 2007, Human evolution and Christian ethics, Cambridge University Press, Cambridge. http://dx.doi.org/10.1017/CBO9780511550935

Post, S., 2011, 'Sanctity of life', in J.B. Green (ed.), Dictionary of Scripture and ethics, pp. 702-703, Baker Publishing Group, Grand Rapids. 
Rooms-Katolieke Kerk (RKK), 2008, 'Congregation for the doctrine of the faith Instruction dignitas personae on certain bioethical questions', in Holy See, viewed
on 20 December 2012, from http://www.vatican.va/roman_curia/congregations/ cfaith/documents/rc_con_cfaith_doc_20081208_dignitas-personae_en.html

Runzheimer, J. \& Larzen, L.J., 2011, 'Medical ethics for Dummies', Beskikbaar by http://www.amazon.com. (Kindle uitgawe).

Seiple, R.A., 2010, 'Christianity, human rights, and a theology that touches the ground', in J.R. Witte \& F.S. Alexander (eds.), Christianity and human rights. An introduction, pp. 320-334, Cambridge University Press, Cambridge. http://dx.doi. org/10.1017/CBO9780511761713.018

Starke, E., 2001, 'Human dignity', in E. Fahlbusch, J.M. Lochman, J. Mbiti, J. Pelikan \& L. Vischer (eds.), Encyclopedia Christianity, vol. 2, E-I, pp. 602-604, William B. $\&$ L. Vischer (eds.), Encyclopedia Christianity, vol. 2, E-l, pp.
Eerdmans Publishing Company Brill, Grand Rapids, Michigan.

Sulmasy, D.P., 2008, 'Dignity and bioethics: History, theory, and selected applications', in Human dignity and bioethics: Essays commissioned by the President's Council on Bioethics, viewed 08 October 2008, from http://bioethics.georgetown.edu/ on Bioethics, viewed 08 Octo
pcbe/reports/human_dignity/

Tada, J.E. \& Cameron, M. de S., 2006, How to be a Christian in a brave new world, Zondervan, Grand Rapids.

Ten Have, H., 2011, Bioethiek zonder Grenzen. Mondialisering van Gezondheid, Ethiek en Wetenschap, Valkhof Pers, Antwerpen.

United Nations (UN), 1948, 'The Universal Declaration of Human rights', viewed on 20 November 2012, from http://www.un.org/en/documents/udhr/index.shtml\#a8

United Nations (UN), [1966a] 1976, 'International Covenant on Civil and Politica Rights', viewed on 20 November 2012, from http://www2.ohchr.org/english/law/ ccpr.htm\#part

United Nations (UN), [1966b] 1976, 'International Covenant on Economic, Social and Cultural Rights', viewed on 20 November 2012, from http://www2.ohchr.org/ english/law/cescr.htm\#part1

United Nations Educational, Scientific and Cultural Organization (UNESCO), 1997 'Universal Declaration on the Human Genome and Human Rights', viewed on 14 June 2012, from http://www.unesco.org/new/en/social-and-human-sciences/ themes/bioethics/human-genome-and-human-rights/

United Nations Educational, Scientific and Cultural Organization (UNESCO), 2004, 'Results of the written consultation on the third outline of the text of a declaration on universal norms on bioethics (27 August 2004)', viewed on 14 June 2012, from http://portal.unesco.org/shs/fr/files/7190/11062332491Consultation_ en.pdf/ Consultation_en.pdf
United Nations Educational, Scientific and Cultural Organization (UNESCO), 2005, 'Explanatory Memorandum on the Elaboration of The Preliminary Draft Declaration on Universal Norms on Bioethics', viewed on 14 June 2012, from http://unesdoc.unesco.org/images/0013/001390/139024e.pdf

United Nations Educational, Scientific and Cultural Organization (UNESCO), 2006 'Universal Declaration on Bioethics and Human Rights', viewed on 14 June 2012, from http://unesdoc.unesco.org/images/0014/001461/146180E.pdf

United Nations Educational, Scientific and Cultural Organization (UNESCO), 2008, 'Bioethics core curriculum. Section 1: Syllabus ethics education programme sector for Social And Human Sciences Division of Ethics of Science and Technology', viewed on 14 June 2012, from http://unesdoc.unesco.org/ Technology', viewed on 14 Jun
images/0016/001636/163613e.pdf

Van Wyk, J.H., 1991, 'Moraliteit en verantwoordelikheid: Opstelle oor politieke etiek', in Wetenskaplike bydraes van die PU vir CHO, Reeks A, Geesteswetenskappe, 77, $\mathrm{PU}$ vir CHO, Potchefstroom.

Veatch, R.M., 2012, 'Hippocratic, Religious, and Secular Medical Ethics: The Points of Conflict', viewed n.d., from http://www.amazon.com. (Kindle edition).

Vorster, J.M., 2004, Ethical perspectives on human rights, Potchefstroom Theological Publications, Potchefstroom. PMCid:PMC404094

Vorster, J.M., 2007, Christian attitude in the South African liberal democracy, Potchefstroom Theological Publications, Potchefstroom.

Vorster, J.M., 2008, The challenge of contemporary religious fundamentalism, Thabang, Pretoria.

Vorster, N., 2011, Created in the image of God. Understanding God's relationship with humanity, Pickwick Publications, Oregon.

Waldron, J., 2010, 'The image of God: Rights, reason, and order', in J.R. Witte \& F.S. Alexander (eds.), Christianity and human rights. An introduction, pp. 216-235, Cambridge University Press, Cambridge. http://dx.doi.org/10.1017/ CBO9780511761713.012

Wright, C.J.W., 1995, 'Old Testament and ethics', in D.J. Atkinson \& D.H. Field (eds.), New dictionary of Christian ethics and pastoral theology, pp. 48-56, Intervarsity, Downers Grove.

Yiu, S., 2012, 'Towards an evangelical social justice: An analysis of the concept of the Kingdom of God and the mission of the Church', PhD thesis, Dept. of Theology, North-West University. 